\title{
A Child with Acute Appendicitis Secondary to Blunt Abdominal Trauma: A Case Report and Review of the Literature
}

\author{
Künt Batın Travmasına İkincil Akut Apandisit Gelişen Bir Çocuk Olgu: Olgu Sunumu ve \\ Literatürün Taraması
}

\author{
(D) Aykut Çağlar ${ }^{1}$, (D) Anıl Er ${ }^{1}$, (D) Özge Atacan², (D) Pelin Gülcü ${ }^{3}$, (D) Sinan Genç ${ }^{3}$, (D) ilknur Çağlar ${ }^{4}$, (D) Tanju Çelik ${ }^{1}$, (D) Hurşit Apa ${ }^{1}$ \\ 1 University of Health Sciences, Dr. Behçet Uz Children's Diseases and Surgery Training and Research Hospital, Clinic of Pediatric Emergency, \\ izmir, Turkey \\ 2 University of Health Sciences, Dr. Behçet Uz Children's Diseases and Surgery Training and Research Hospital, Clinic of Pediatric Surgery, \\ Izmir, Turkey \\ 3 University of Health Sciences, Dr. Behçet Uz Children's Diseases and Surgery Training and Research Hospital, Clinic of Radiology, izmir, Turkey \\ 4 University of Health Sciences, Dr. Behçet Uz Children's Diseases and Surgery Training and Research Hospital, Clinic of Pediatric \\ Infectious Disease, Izmir, Turkey
}

\section{Abstract}

We present a child with abdominal pain and vomiting after blunt abdominal trauma (BAT). He had tenderness, guarding and rebound on the bilateral lower quadrant of the abdomen. He had no abrasion on the abdominal skin surface. He had marked leukocytosis and increased C-reactive protein level. Contrastenhanced abdominal computed tomography revealed inflamed appendicitis. He was operated by pediatric surgeons and, an perforated appendix was illustrated on pathological examination. BAT and acute appendicitis (AA) are independently very frequent issues. In pediatric emergency departments, BAT and AA are very frequent issues, however, coexistence of these two condition in the same patient is rare. This case report and review of the literature showed that occurrence of AA after BAT should be considered by emergency physicians.

Keywords: Child, appendicitis, abdominal injuries

\section{Öz}

Bu raporda künt batın travması (BAT) sonrasında karın ağrısı ve kusma ile çocuk acil servisine başvuran bir olgu sunulmaktadır. Başvuru anında, hastanın karın muayenesinde yaygın hassasiyet, bilateral alt kadranlarda defans ve rebound mevcuttu. Laboratuvar tetkiklerinde belirgin lökositoz ve artmış C-reaktif protein değeri tespit edildi. Kontrastlı batın tomografisinde akut apandisit görülen hasta, çocuk cerrahisi tarafında ameliyat edildiğinde makroskopik ve mikroskopik olarak perfore apandisit ile uyumlu olduğu belirlendi. BAT ve akut apandisit (AA) acil servislerde birbirinden bağımsız olarak sıklıkla karşılaşılan durumlar olmasına karşın nadir de olsa aynı anda görülebilmektedir. Travmanın AA gelişiminde bir etken olup olmadığı konusunda literatürde kısıtlı bilgiler mevcuttur. Bu olguyu sunmaktaki amacımız, acil hekimlerinin BAT sonrasında AA gelişebileceği konusunda farkındalığını arttırmaktır.

Anahtar Kelimeler: Çocuk, apandisit, abdominal yaralanma

\section{Introduction}

Acute appendicitis (AA) is the most common disease which requires surgical intervention in pediatric emergency settings. ${ }^{1}$ Although there are various factors in the pathophysiology, the main cause of $A A$ is obstruction of the lumen with stool, food, lymphoid nodules, appendicolitis or neoplasms. ${ }^{2}$ In the literature, there are limited data on the fact that trauma may cause AA. ${ }^{3}$ Here, we present a case of perforated appendicitis occurring after blunt abdominal trauma (BAT). We aimed to emphasize that emergency physicians should consider BAT as a rare cause of $A A$.

Address for Correspondence/Yazışma Adresi: Aykut Çağlar MD, University of Health Sciences, Dr. Behçet Uz Children's Diseases and Surgery Training and Research Hospital, Clinic of Pediatric Emergency, İzmir, Turkey

E-mail: aykutcaglar@gmail.com ORCID ID: orcid.org/0000-0002-2805-5420

Received/Geliș Tarihi: 07.11.2017 Accepted/Kabul Tarihi: 23.01.2018

${ }^{\circ}$ Copyright 2018 by Society of Pediatric Emergency and Intensive Care Medicine

Journal of Pediatric Emergency and Pediatric Intensive Care published by Galenos Yayınevi. 


\section{Case}

A-12-year-old boy was admitted to the pediatric emergency department (ED) with abdominal pain and vomiting. He had a history of fall from a swing that had caused BAT one day before admission. On admission, he was conscious but anxious because of abdominal pain. The body temperature was $36.2{ }^{\circ} \mathrm{C}$, heart rate was 84/ minute, and arterial blood pressure was 105/60 $\mathrm{mmHg}$. The chest was clear, breath sounds vesicular and he had a respiratory rate of $22 /$ minute. There was tenderness, guarding and rebound bilaterally on the lower quadrant of the abdomen, and no abrasion on the abdominal skin surface. In the laboratory tests, his leukocyte count was $21020 / \mu \mathrm{L}$, absolute neutrophil count was $18730 / \mu \mathrm{L}$, and C-reactive protein level was $3.56 \mathrm{mg} / \mathrm{dL}$. His liver and renal function tests were normal. In the urine sample test, there was ketonuria but no hematuria or pyuria. Plain abdominal $x$-ray revealed diffuse air-fluid levels (Figure 1). Abdominal computed tomography was performed for traumatic injury and showed that there was no vital organ injury, but inflamed acute appendix and minimal pelvic free fluid (Figure 2). Under general anesthesia, surgical resection of the inflamed and perforated appendix was performed by pediatric surgeons, and no complication was observed.

Pathological examination was consistent with AA and also bleeding on the tip of the appendix was noted. The patient healed completely without complication and was discharged three days after operation.

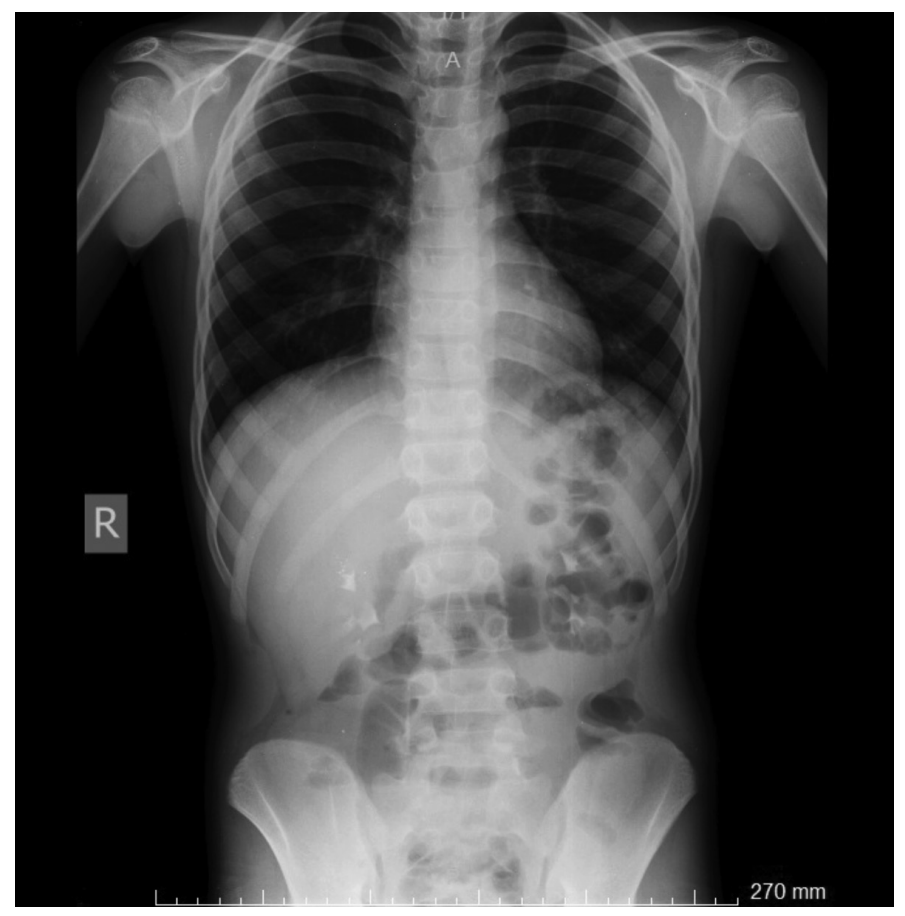

Figure 1. Plain radiograph shows diffuse air - fluid levels

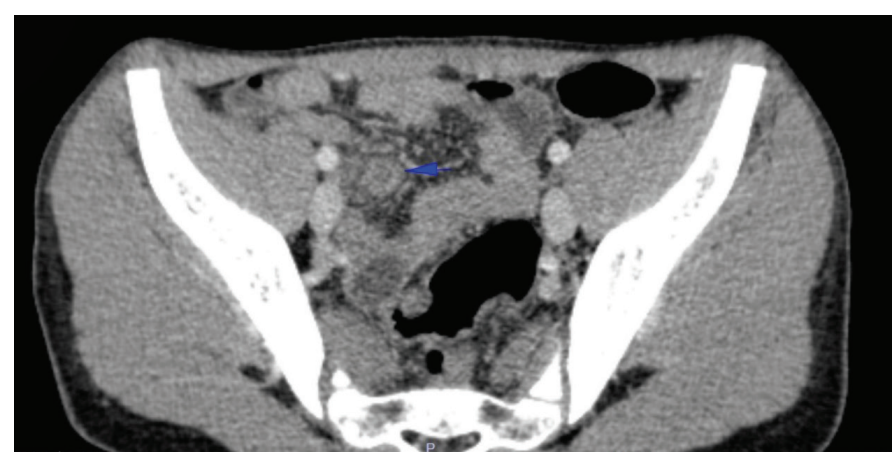

Figure 2. Computed tomography reveal that appendicitis by thickening of the appendix wall, and contrast - enhancing (Blue arrow)

\section{Discussion}

Trauma is a rare cause of AA. However, there is still a debate about whether this is a real cause or just a coincidence. Ciftci et al. ${ }^{4}$ enrolled 554 children in their study and reported that the incidence of BAT as a causative factor for AA was $0.9 \%$. Additionally there are few case reports in the literature. Fowler ${ }^{5}$ defined five essential criteria for AA caused by BAT in their study which was reported in the 1938. First of all, there must be no history of abdominal pain attack suggestive of AA before trauma and secondly, the mechanism of trauma must be directly related to abdominal region and affect the appendix. The effect of injury must be experienced immediately after the occurrence of AA symptoms. Besides, the traumatic lesion of the appendix must be demonstrated operatively and the pathologic diagnosis of AA must be made. To our knowledge, there are 22 pediatric cases, including our patient, meeting the criteria for BAT-related AA in the literature (Table 1). 3,4,6-14 Most of these patients were boys (86.4\%), and the mean \pm standard deviation age of the patients was 10.0 (3.3) years. The median (interquartile range) time between admission and injury was 4.0 (1.0-12.0) hours. Abdominal tenderness and fever were prominent findings in most of the cases. Our patient had diffuse abdominal tenderness, rebound, and guarding as well but no fever. Leukocytosis was the remarkable laboratory test in all patients as in our patient. Eleven (50\%) patients had associated injury. Pathological investigation of all cases had revealed findings of $A A$. Perforation was noted in six patients (27.2\%).

The mechanism of occurrence of BAT-related AA is not clear. There are a few theories. Fowler ${ }^{5}$ defined that occurrence of BAT-related AA can be caused by direct or indirect pressure on the abdomen. Sharma et al. ${ }^{15}$ proposed a theory based on LaPlace's law; when intra abdominal pressure increased instantly, the caecum, the widest part of the intestine, becomes the most susceptible region for the surface tension. An increase in the ceacum surface tension can cause obstruction of the orifice of the appendix secondary to the mucosal 
Table 1. Characteristics of the blunt abdominal trauma related pediatric acute appendicitis patients in the literature

\begin{tabular}{|c|c|c|c|c|c|c|c|c|c|c|}
\hline Authors & No & Age & Sex & Mechanism & $\begin{array}{l}\text { The interval } \\
\text { between } \\
\text { injury and } \\
\text { admission }\end{array}$ & $\begin{array}{l}\text { Associated } \\
\text { injuries }\end{array}$ & Perforation & $\begin{array}{l}\text { WBC } \\
/ \mu \mathrm{L}\end{array}$ & $\begin{array}{l}\text { Fever } \\
{ }^{\circ} \mathrm{C}\end{array}$ & Physical findings \\
\hline Ciftci et al. ${ }^{4}$ & 1 & 8 & M & MVA & $2 \mathrm{~h}$ & $\mathrm{HI}$ & + & N/A & N/A & DT, guarding \\
\hline Ciftci et al. ${ }^{4}$ & 2 & 5 & $\mathrm{~F}$ & Fall & $6 \mathrm{~h}$ & Rib fracture & & N/A & N/A & RLQT \\
\hline Ciftci et al. ${ }^{4}$ & 3 & 13 & $\mathrm{~F}$ & Struck by ball & $12 \mathrm{~h}$ & NIL & & N/A & N/A & RLQT \\
\hline Ciftci et al 4 & 4 & 14 & M & MVA & $4 \mathrm{~h}$ & $\mathrm{HI}$ & + & N/A & N/A & DT, guarding \\
\hline Ciftci et al. ${ }^{4}$ & 5 & 7 & M & Assault & $12 \mathrm{~h}$ & $\mathrm{HI}$ & & N/A & N/A & RLQT, guarding \\
\hline Etensel et al. ${ }^{14}$ & 6 & 5 & M & MVA & $4 \mathrm{~h}$ & $\mathrm{HL}$ & - & 18700 & 36.5 & DT \\
\hline Etensel et al. ${ }^{14}$ & 7 & 8 & M & MVA & $1 \mathrm{~h}$ & $\mathrm{DR}, \mathrm{HL}, \mathrm{RH}$ & - & 19500 & 38.5 & DT \\
\hline Etensel et al. ${ }^{14}$ & 8 & 14 & M & MVA & $1 \mathrm{~h}$ & $\mathrm{LC}, \mathrm{RF}, \mathrm{RH}, \mathrm{FF}$ & - & 18700 & 36.8 & DT, rebound \\
\hline Etensel et al. ${ }^{14}$ & 9 & 9 & M & Fall & $1 \mathrm{~h}$ & LC, FF & - & 17700 & 36.7 & Mild tenderness \\
\hline Etensel et al. ${ }^{14}$ & 10 & 13 & M & MVA & 15 minute & $\mathrm{DR}, \mathrm{SL}, \mathrm{UPH}$ & - & 19400 & 37.1 & DT \\
\hline $\begin{array}{l}\text { Hennington et } \\
\text { al. }{ }^{8}\end{array}$ & 11 & 12 & M & $\begin{array}{l}\text { Bicycle } \\
\text { handlebar injury }\end{array}$ & $12 \mathrm{~h}$ & - & - & 13000 & 38.2 & DLQT, guarding \\
\hline $\begin{array}{l}\text { Musemeche } \\
\text { and Baker }{ }^{9}\end{array}$ & 12 & 4 & M & MVA & $72 \mathrm{~h}$ & $\mathrm{HL}, \mathrm{SL}, \mathrm{PE}$ & + & 22900 & 39.5 & $\begin{array}{l}\text { Abdominal distention, } \\
\text { DT }\end{array}$ \\
\hline Osterhoudt 10 & 13 & 9 & M & MVA & $1 \mathrm{~h}$ & & & N/A & N/A & RLQT, guarding \\
\hline Ramesh et al. ${ }^{11}$ & 14 & 11 & M & $\begin{array}{l}\text { Bicycle } \\
\text { handlebar injury }\end{array}$ & $48 \mathrm{~h}$ & - & + & Raised & Raised & DLQT \\
\hline Ramsook $^{12}$ & 15 & 12 & M & Kick & $7 \mathrm{~h}$ & - & - & 15400 & 38.6 & DT \\
\hline Serour et al. ${ }^{13}$ & 16 & 11 & M & Punch & $18 \mathrm{~h}$ & - & - & 11400 & 38.0 & RLQT, guarding \\
\hline Serour et al. ${ }^{13}$ & 17 & 8 & M & Fall & $3 \mathrm{~h}$ & - & - & 20100 & 38.2 & $\begin{array}{l}\text { Ecchymosis, RLQT, } \\
\text { guarding, rebound }\end{array}$ \\
\hline Serour et al. ${ }^{13}$ & 18 & 7 & M & & & & & N/A & 40 & DT, rebound, guarding \\
\hline Amir et al. ${ }^{6}$ & 19 & 10 & M & Fall & $2 \mathrm{~h}$ & - & - & N/A & 36.5 & Ecchymosis, DT \\
\hline Paschos et al. ${ }^{7}$ & 20 & 17 & $\mathrm{~F}$ & $\begin{array}{l}\text { Bicycle } \\
\text { handlebar injury }\end{array}$ & $1 \mathrm{~h}$ & - & - & 12700 & 37.5 & Echymosis, DT \\
\hline Toumi et al. ${ }^{3}$ & 21 & 11 & $M$ & Fall & $3 \mathrm{~h}$ & - & - & Raised & Raised & RLQT \\
\hline Our patient & 22 & 12 & $\mathrm{M}$ & Fall & $24 \mathrm{~h}$ & - & + & 21020 & 36.2 & $\begin{array}{l}\text { DRQT, Rebound, } \\
\text { guarding }\end{array}$ \\
\hline
\end{tabular}

straining, hemorrhage, and clot formation. Hennington et al. ${ }^{8}$ reported that edema formation, hematoma, and/or lymph node hyperplasia can result from trauma, and may cause obstruction of the appendix lumen. Our patient's pathological examination revealed that there was a mucosal hemorrhage on the tip of the appendix which was consistent with the mechanism proposed by Hennington et al. ${ }^{8}$

In pediatric emergency departments, BAT and AA are very frequent issues. Although rare, they might occur coincidentally in the same patient. This case report and review of the literature showed that occurrence of AA after BAT should be kept in mind by emergency physicians.

\section{Ethics}

Informed Consent: Writen consent was obtained.

Peer-review: Externally and internally peer-reviewed.

\section{Authorship Contributions}

Surgical and Medical Practices: A.Ç., A.E., H.A., Ö.A., P.G., S.G., T.Ç., Concept: A.Ç., A.E., H.A., Design: A.Ç., A.E., i.ç., Data Collection or Processing: A.Ç., Ö.A., Analysis or Interpretation: A.Ç., A.E., H.A., Ö.A., P.G., S.G., T.Ç., Literature Search: A.Ç., A.E., T.Ç., Writing: A.E., I.Ç.

Conflict of Interest: No conflict of interest was declared by the authors.

Financial Disclosure: The authors declared that this study received no financial support.

\section{References}

1. Benabbas R, Hanna M, Shah J, Sinert R. Diagnostic Accuracy of History, Physical Exam, Laboratory Tests and Point-of-CareUltrasound for Pediatric Acute Appendicitis in the Emergency 
Department: A Systematic Review and Meta-Analysis. Acad Emerg Med. 2017;24:523-51.

2. Rentea RM, Peter SD, Snyder CL. Pediatric appendicitis: state of the art review. Pediatr Surg Int. 2017;33:269-83.

3. Toumi Z, Chan A, Hadfield MB, Hulton NR. Systematic review of blunt abdominal trauma as a cause of acute appendicitis. Ann R Coll Surg Engl. 2010;92:477-82.

4. Ciftci AO, Tanyel FC, Buyukpamukcu N, et al. Appendicitis after blunt abdominal trauma: cause or coincidence? Eur J Pediatr Surg. 1996;6:350-3

5. Fowler $\mathrm{RH}$. The rare incidence of acute appendicitis resulting from external trauma. Ann Surg. 1938;107:529-39.

6. Amir A, Amir L, Waisman Y. Acute appendicitis after a blunt perineal trauma: an illustrative case. Pediatr Emerg Care. 2009;25:184-5.

7. Paschos KA, Boulas K, Liapis A, Georgiou E, Vrakas X. Traumatic appendicitis in minor blunt abdominal injury. Emerg Med Australas. 2012;24:343-6.
8. Hennington $\mathrm{MH}$, Tinsley EA Jr, Proctor HJ, Baker CC. Acute appendicitis following blunt abdominal trauma. Incidence or coincidence? Ann Surg. 1991;214:61-3.

9. Musemeche CA, Baker JL. Acute appendicitis: a cause of recurrent abdominal pain in pediatric trauma. Pediatr Emerg Care. 1995;11:30-1.

10. Osterhoudt KC. Hocus-pocus: a case of abdominal pain after blunt abdominal trauma. Pediatr Ann. 2000;29:93-6.

11. Ramesh G, Ho PW, Ng KL, Jegan T. Appendicitis following blunt abdominal trauma. Med J Malaysia. 2002;57:123-4.

12. Ramsook C. Traumatic appendicitis: fact or fiction? Pediatr Emerg Care. 2001;17:264-6.

13. Serour F, Efrati Y, Klin B, Shikar S, Weinberg M,et al. Acute appendicitis following abdominal trauma. Arch Surg. 1996;131:785-6.

14. Etensel B, Yazici M, Gursoy H, Ozkisacik S, Erkus M. The effect of blunt abdominal trauma on appendix vermiformis. Emerg Med J. 2005;22:874-7.

15. Sharma AK, Vig S, Neades GT. Seat-belt compression appendicitis. Br J Surg. 1995;82:999. 